Folia primat. 1970;13:I-IV

\title{
Contents, Vol. 13, 1970
}

Editor:

J. Biegert, Zurich

Editorial Board:

E. L. Bone, Louvain

W. Fiedler, Wien

H. F. Harlow, Madison, Wise.

H. Hediger, Zurich

W. C. Osman Hill, Folkestone

H. Hofer, Covington, La.

J. Hürzeler, Basel

J. R. Napier, London

J. Piveteau, Paris

A. Remane, Kiel

A. H. Schultz, Zurich

D. Starck, Frankfurt am Main

W. L. Straus, Jr., Baltimore, Md.

S. L. Washburn, San Francisco, Calif.

H. Zapfe, Wien

S. Zuckerman, Birmingham

s\$fik

S. Karger $\cdot$ Basel (Switzerland) $\cdot$ München $\cdot$ Paris $\cdot$ New York

S. Karger AG, Arnold-Böcklin-Strasse 25, CH-4000 Basel 11 (Switzerland)

All rights, including that of translation into other languages, reserved. Photomechanic reproduction (photocopy, microcopy) of this volume or parts thereof without special permission of the publishers is prohibited.

CCopyright 1970by S. Karger AG, Verlag für Medizin und Naturwissenschaften, Basel Printed in Switzerland by Schellenberg-Druck, Pfăfffikon ZH

Contents

Adey, W. R.: vide Freemon, F. R.

Bergeron, J. A. and Buettner-Janusch, J.: Hematology of Prosimian Primates:

Galago, Lemur and Propithecus 155

Bergeron, J. A. and Buettner-Janusch, J.: Hematology of Prosimian Primates.

II. A Comparative Study of Lemuriformes in Captivity in Madagascar and North Carolina 306

Blakley, G. A.: Luteinizing Hormone Levels in Nonhuman Primates 
Bosman, A. R.: vide Brink, A. J.

Brink, A. J.; Lewis, C. M.; Bosman, A. R., and Lochner, A.: The Baboon (Papio ursinus) Heart (Coronary Blood Supply, Muscle Function and Meta

bolism) $\quad 11$

Buettner-Janusch, J. and Wiggins, R. C.: Haptoglobins and Acid Phosphatases

of Galago 166

Buettner-Janusch, J.: vide Bergeron, J. A.

Buettner-Janusch, J.: vide Coppenhaver, D.

Buss, D. H. and Cooper, R. W.: Composition of Milk from Talapoin Monkeys . 196

Butler, H.: Septic Abortion in the Senegal Bush Baby (Galago senegalensis senegalensis) 207

Christen, P.; Peacock, W. C; Christen, Anita E., and Wacker, W. E. C: Urate

Oxidase in Primates 35

Christen, Anita E.: vide Christen, P.

Cooper, R. W.: vide Buss, D. H.

Coppenhaver, D., and Buettner-Janusch, J.: Transferrins of Cercopithecinae ... 23

Dillyngham, L. A.: vide Heүnrichs, W. L.

Epple, Gisela: Quantitative Studies on Scent Marking in the Marmoset (Callithrix jacchus) $\quad 48$

Freemon, F. R.; McNew, J. J., and Adey, W. R.: Sleep of Unrestrained Chimpanzee:

Differences Between First and Last Rapid Eye Movement Periods .... 144

Glaser, D.: Geschmacksschwellenwerte von verschiedenen Zuckerarten bei Calli-

thricidae (Platyrrhina) 40

Hampton, S. H.: vide Hsu, T. C.

Heinrichs, W. L. and Dillingham, L. A.: Bornean Orang-Utan Twins Born in

Captivity $\quad 150$

Hershkov $\gamma \gamma$ z, P.: Cerebral Fissural Patterns in Platyrrhine Monkeys

213

Hsu, T. C. and Hampton, S. H.: Chromosomes of Callithricidae with Special Refe rence to an XX/'XO' Sex Chromosome System in Goeldi's Marmoset

(Callimico goeldii Thomas 1904) 183

Lewis, C. M.: vide Brink, A. J.

Lochner, A.: vide Brink, A. J.

Loy, J.: Peri-Menstrual Sexual Behavior Among Rhesus Monkeys 286

IV

Contents

Kanagasuntheram, R.: vide Wong, W. C.

Klopfer, P. H.: Discrimination of Young in Galagos 137

Marler, P.: Vocalizations of East African Monkeys. I. Red Colobus 81

McNew, J. J.: vide Freemon, F. R. Peacock, W. C.: vide Christen, P.

Planas, J.: Haptoglobins in Chimpanzees and Gorillas 177

Poirier, F. E.: The Communication Matrix of the Nilgiri Langur (Presbytisjohnii)

of South India 92

Rahlmann, D. F.: The Hemodynamics of the Pig-tailed Monkey (Macaca nemestrina) 1

Van Horn, R. N.: Vibrissae Structure in the Rhesus Monkey

Wacker, W. E. C.: vide Christen, P. 
Wiggins, R. C.: vide Buettner-Janusch, J.

Wong, W. C. and Kanagasuntheram, R.: Effects of Median Nerve Injury on Some

Digital Tissues of the Hand of the Macaque (Macaca fascicularis) .... 63

Book Reviews - Buchbesprechungen - Livres nouveaux 74, 314 